\title{
Activity of a psychologist in a Medical Specialties Unit: Ambulatory Center for the Prevention and Attention of AIDS and other sexually transmitted infections.
}

\author{
Actividad del psicólogo en las Unidades de Especialidades Médicas: Centro Ambulatorio Para la \\ Prevención en Síndrome de Inmunodeficiencia Adquirida e Infecciones de Transmisión Sexual.
}

Mario Diego-Martínez, ${ }^{a}$ Vanessa Caballero de Carranza-Ayala ${ }^{b}$

\begin{abstract}
:
Introduction: The attention provided at Medical Specialties Unit (UNEME), Ambulatory Center for the Prevention and Attention of AIDS and other sexually transmitted diseases (CAPASITS), the psychologist develops activities that strengthen the patients' treatment, as a part of a multidisciplinary work. In this way, it becomes essential knowing the importance of the psychologist activities and how they get involved in the Public Health problems. Objective: To analyze the professional competencies that psychologists must possess and how they apply them in their activity at the UNEME CAPASITS Material and Methods: A descriptive bibliographic review was carried out. For the inclusion criteria, it was considered that they will report on: the development of professional skills of health psychologists, the activity of psychologists in public health institutions, development of professional skills of the psychologist and the objectives of health psychology. To search for information, the following keywords were used: health psychology, activity and professional skills. The bibliographic search was performed in the databases: EBSCO, ScienceDirect, Dialnet, PubMed, REdalyc, ResearchGate and pages from official sites: WHO and the National Center for the Prevention and Control of HIV and AIDS. Results: From the analyzed information it was found that the professional competencies that the psychologist must possess in the field of health are focused on the management of preventive strategies, use of health technologies, creation of plans and programs to promote a healthy lifestyle, evaluation and treatment as well as collaborative work. Conclusions: The UNEMES CAPSITS require that psychologists possess competencies such as: communication, use of information and communication technologies (ICT), research, evaluation for treatment, monitoring and creation of clinical records, in addition to: research for health and the dissemination of the results, especially in the treatments.
\end{abstract}

\section{Keywords:}

Health psychologist, activity, professional skills.

\section{Resumen:}

Introducción: En la atención brindada en las Unidades de Especialidades Médicas (UNEME), Centro Ambulatorio para la Prevención y Atención del Sida y otras Infecciones de Transmisión Sexual (CAPASITS), el psicólogo realiza actividades que fortalecen el acompañamiento en los tratamientos hacia los pacientes, como parte de un trabajo multidisciplinario. De esta manera, es indispensable conocer el tipo de actividad que desempeña y como se involucra en problemas de Salud Pública. Objetivo: Analizar las competencias profesionales que debe poseer el psicólogo y cómo las aplica en su actividad en UNEME CAPASITS Material y métodos: Se realizó una revisión bibliográfica del tipo descriptiva, para los criterios de inclusión se consideró que informarán sobre: el desarrollo de competencias profesionales del psicólogo de la salud, actividad del psicólogo en instituciones de salud pública, procedimiento y desarrollo de competencias profesionales del psicólogo y objetivos de la psicología de la salud y para la búsqueda de la información, se usaron palabras clave como: psicología de la salud, actividad y competencias profesionales. La búsqueda bibliográfica se realizó en las bases: EBSCO, ScienceDirect, Dialnet, PubMed, REdalyc, ResearchGate y páginas de sitios oficiales: WHO y Centro Nacional para la Prevención y Control del VIH y el sida.Resultados: De la información analizada se encontró que las competencias profesionales que debe poseer el psicólogo en el ámbito de la salud están enfocadas al manejo de estrategias preventivas, uso de las tecnologías en salud, creación de planes y programas para favorecer un estilo de vida saludable, evaluación y tratamiento así como trabajo colaborativo. Conclusiones: Las UNEMES CAPSITS requieren que los psicólogos posean competencias como: comunicación, uso de las tecnologías de la información y la comunicación (TIC), investigación, evaluación para el tratamiento, seguimiento y creación de expedientes clínicos, además de: la investigación para la salud y la divulgación de los resultados, sobre todo en los tratamientos.

${ }^{a}$ Corresponding Autor: Mario Diego Martínez. Consultorio Particular. Pachuca Hidalgo. México. https://orcid.org/0000-0003-2093-7899, Email: psic.mdm@gmail.com

b Vanessa Caballero de Carranza-Ayala. Consultorio Particular. Pachuca Hidalgo. México. https://orcid.org/0000-0002-7287-7552, Email: vcaballerocarranza@gmail.com 
Palabras Clave:

Psicólogo de la salud, actividad, competencias profesionales.

\section{INTRODUCTION}

"As more psychologists come into contact with a greater variety of aspects of physical medicine, we may expect this to lead to many new interesting lines of laboratory research and also to new practical applications in prevention, diagnosis, and therapy". In following lines we are going to distinguish specific activities of health psychologists to avoid ambiguities with similar areas of psychology. The main topic in this research is, primarily, to identify which kind of activity the psychologists develop at a Medical Specialties Unit (UNEME) Ambulatory Center for the Prevention and Attention of AIDS and other sexually transmitted infections (CAPASITS), so we can easily understand their importance.

Since health psychology formally started at APA with the intention of giving support to the healthcare area and health promotion, prevention and treatment of diseases, even health policies, ${ }^{2}$ It represented a real challenge, because we had to distinguish its activities from those of other psychology areas to prevent a mistaken representation of what it means of can mean. ${ }^{3}$

Health psychology can be defined as "the educational, scientific and professional contributions of the psychology discipline to promote and preserve health, prevent and treat diseases,, identify etiologies and diagnosis related to health, diseases and other disfunctions, as well as the improvement of the healthcare system and the creation of health policies". "When psychology was created as a discipline it intended to contribute to the scientific knowledge in the dichotomy health-disease through research and psychological knowledge. These contributions would be addressed not only to biomedical sciences, but also to the general population so they would know the results of those researches. ${ }^{4}$

However, to understand that meaning, we must refer to the concept of health which transformed from "absence of disease", to a "complete physical, mental and social well-being and not just the absence of disorders or diseases". ${ }^{5}$ From the appearance of this concept, the "mental" aspect was involved, considering a deeper meaning (which, due to the nature of this article it should not be left aside, since it must be considered to understand the relationship between the concept of health and health psychology). In this sense, the mental health is part of the conceptual structure and of what each individual possess, as part of primary health care services. ${ }^{6}$

So far, general points from the relationship between psychology and health are identified, even though when speaking about health it is directly associated with the physical element more than with the behavioral, mental or psychological element. ${ }^{7}$ So psychology is involved in a multidisciplinary activity, given than it covers health care, health care policies and protection. The following table shows the objectives of health psychology. ${ }^{8}$

In Table 1 these objectives are organized and an association with the activities carried out by the psychologist at CAPASITS, according to its procedures manual, is made.

Table 1. Relation between the objectives of health psychology and the activity of a psychologist at CAPSITS.

\begin{tabular}{|c|c|c|c|}
\hline \multicolumn{4}{|c|}{ Objectives form health psychology } \\
\hline $\begin{array}{l}1 .- \\
\text { Health } \\
\text { promotion. }\end{array}$ & $\begin{array}{l}\text { 2.- } \\
\text { Prevention } \\
\text { of diseases }\end{array}$ & $\begin{array}{l}\text { 3.- } \\
\text { Treatment } \\
\text { and } \\
\text { evaluation of } \\
\text { specific } \\
\text { diseases. }\end{array}$ & $\begin{array}{l}\text { 4.- } \\
\text { Evaluation } \\
\text { and } \\
\text { improvement } \\
\text { of the } \\
\text { healthcare } \\
\text { system. }\end{array}$ \\
\hline $\begin{array}{l}\text {-Promotion } \\
\text { of healthy } \\
\text { life styles. } \\
\text {-Encourage } \\
\text { healthy } \\
\text { habits so } \\
\text { people feel } \\
\text { better in } \\
\text { their daily } \\
\text { life. }\end{array}$ & $\begin{array}{l}\text {-Change of } \\
\text { unhealthy } \\
\text { habits } \\
\text { associated } \\
\text { to different } \\
\text { chronic or } \\
\text { acute } \\
\text { pathologies. }\end{array}$ & $\begin{array}{l}\text { Psychologist } \\
\text { works with } \\
\text { other health } \\
\text { specialists } \\
\text { mixing } \\
\text { treatments, } \\
\text { based on a } \\
\text { behavior } \\
\text { modification. }\end{array}$ & $\begin{array}{l}\text {-Consider all } \\
\text { the proposals } \\
\text { addressed to } \\
\text { improve the } \\
\text { healthcare } \\
\text { attention, } \\
\text { besides } \\
\text { creating } \\
\text { public } \\
\text { policies. }\end{array}$ \\
\hline
\end{tabular}

The four objectives are addressed to imrove the population's health. Nevertheless, considering that what is intended is to identify the importance of the activity of the health psychologist at CAPSITS, the objective number 3 is related to the multidisciplinary work already mentioned which has a direct impact on the evaluation, treatment and follow-up of people with sexually transmitted infections and AIDS, because it is a combination of the work of regular physicians with psychological treatments. ${ }^{8,9}$

Source: Own elaboration based on the reviewed literature.

Given the above, it is important to consider that the objective of this paper is to analyze the professional competencies that psychologists must possess and how they apply them in their activity at the UNEME CAPASITS. 


\section{MATERIAL AND METHOD}

This study is a descriptive bibliographic review ${ }^{10}$. It was made a search on internet data bases such as EBSCO, ScienceDirect, Dialnet, PubMed, Redalyc, ResearchGate, and pages from official sites: WHO and National Center for the Prevention and Control of HIV and AIDS. The keywords that were used are: health psychology, activity and professional competencies. Spanish and English were also considered. For the inclusion criteria, it was considered that they will inform about: the development of professional competencies of the health psychologist, the activity of a psychologist in public health institutions, development of professional competencies of the psychologist, and the objectives of health psychology. At first, 46 documents were identified after a filter, 20 researches were selected, 4 web sities and 2 complementary texts that met the above criteria, excluding all papers where health psychologist professional competencies were not mentioned.

\section{RESULTS}

From the analysis of the information the following was found.

Table 2 Professional competencies or actions of the health psychologist associated with the CAPASITS manual of procedures.

\begin{tabular}{|c|c|c|}
\hline Author & $\begin{array}{l}\text { Competencies and / or } \\
\text { activity suggested in } \\
\text { the studies }\end{array}$ & $\begin{array}{l}\text { Complies with } \\
\text { the activities } \\
\text { mentioned in } \\
\text { the } \\
\text { CAPASITS } \\
\text { Manual of } \\
\text { Procedures }\end{array}$ \\
\hline \multirow[t]{3}{*}{$\begin{array}{l}\text { Garofalo and Baum. } \\
\text { 1998. }\end{array}$} & $\begin{array}{l}\text { Support in the } \\
\text { treatment of diseases }\end{array}$ & $*$ \\
\hline & $\begin{array}{l}\text { Strengthen social } \\
\text { support }\end{array}$ & $*$ \\
\hline & Decrease stress & $*$ \\
\hline \multirow[t]{5}{*}{ Bazán Riveron. 2003. ${ }^{2}$} & Therapeutic adherence & $*$ \\
\hline & Pain management & $*$ \\
\hline & $\begin{array}{l}\text { Psychosomatic } \\
\text { disorders }\end{array}$ & $*$ \\
\hline & Stress prevention & $* *$ \\
\hline & $\begin{array}{l}\text { Reduction of risk } \\
\text { factors }\end{array}$ & $*$ \\
\hline \multirow[t]{6}{*}{ Piña López. $2010 .^{3}$} & $\begin{array}{l}\text { Detection of health } \\
\text { problems }\end{array}$ & $* *$ \\
\hline & $\begin{array}{l}\text { Psychological } \\
\text { diagnosis }\end{array}$ & $*$ \\
\hline & $\begin{array}{l}\text { Identification } \\
\text { epidemiological } \\
\text { problems }\end{array}$ & $*$ \\
\hline & $\begin{array}{l}\text { Creation of instruments } \\
\text { to diagnose }\end{array}$ & $* *$ \\
\hline & Prevention strategies & $*$ \\
\hline & $\begin{array}{l}\text { Timely detection of } \\
\text { psychological problems }\end{array}$ & $*$ \\
\hline
\end{tabular}

\begin{tabular}{|c|c|c|}
\hline & $\begin{array}{l}\text { Support in the } \\
\text { correction } \\
\text { psychosocial problems } \\
\text { associated with the } \\
\text { disease }\end{array}$ & * \\
\hline Matarazzo. $1982 .^{4}$ & $\begin{array}{l}\text { Helping children and } \\
\text { adults to remain healthy }\end{array}$ & $*$ \\
\hline \multirow{2}{*}{$\begin{array}{l}\text { Saavedra Solano et al. } \\
2016 .{ }^{6}\end{array}$} & Administrative skills & $*$ \\
\hline & Primary care & * \\
\hline \multirow[t]{4}{*}{ Oblitas. $2008 .^{8}$} & Health promotion & $*$ \\
\hline & Prevention of diseases & $*$ \\
\hline & $\begin{array}{lr}\text { Evaluation } & \text { and } \\
\text { treatment of } & \text { specific } \\
\text { diseases } & \end{array}$ & $*$ \\
\hline & $\begin{array}{l}\text { Evaluation } \\
\text { improvement of and } \\
\text { healthcare system }\end{array}$ & $* *$ \\
\hline
\end{tabular}

\begin{tabular}{|c|c|c|}
\hline \multirow{4}{*}{$\begin{array}{lrr}\text { Péres } & \text { Rosiles and } \\
\text { Márquez } & \text { Barradas. } \\
2000 . & \end{array}$} & Attention to behavior & * \\
\hline & $\begin{array}{l}\text { Attention to emotions } \\
\text { and cognition }\end{array}$ & $*$ \\
\hline & $\begin{array}{ll}\begin{array}{l}\text { Treatment } \\
\text { prevention } \\
\text { disease }\end{array} & \text { of } \\
\end{array}$ & $*$ \\
\hline & Health promotion & $*$ \\
\hline $\begin{array}{l}\text { Fernandes Alves et al. } \\
2016^{12}\end{array}$ & $\begin{array}{l}\text { Attention in first, } \\
\text { second and third level } \\
\text { (promotion and } \\
\text { prevention, basic or } \\
\text { specialty healthcare) }\end{array}$ & ** \\
\hline \multirow[t]{2}{*}{ Reynoso et al. 2002. ${ }^{13}$} & Health promotion & $*$ \\
\hline & Prevention of disease & $* *$ \\
\hline \multirow[t]{4}{*}{ Werner et al. 2002. ${ }^{14}$} & $\begin{array}{l}\text { Psychological } \\
\text { treatment }\end{array}$ & * \\
\hline & Collaborative work & * \\
\hline & $\begin{array}{l}\text { Planning and } \\
\text { adherence to treatment }\end{array}$ & * \\
\hline & $\begin{array}{l}\text { Promotion of healthy } \\
\text { behaviors }\end{array}$ & * \\
\hline Weiss. $1982 .{ }^{15}$ & Health care strategies & * \\
\hline \multirow{2}{*}{$\begin{array}{l}\text { Armayones et al. } \\
2015 .{ }^{16}\end{array}$} & Research skills & * \\
\hline & $\begin{array}{l}\text { Use of information and } \\
\text { communication } \\
\text { technologies in health }\end{array}$ & $* *$ \\
\hline \multirow{3}{*}{$\begin{array}{l}\text { Piña and Rivera. } \\
2006 .{ }^{17}\end{array}$} & Investigation & $*$ \\
\hline & Prevention & $*$ \\
\hline & Rehabilitation & $*$ \\
\hline \multirow[t]{2}{*}{$\begin{array}{l}\text { Díaz Facio Lince. } \\
2010 .{ }^{20}\end{array}$} & $\begin{array}{l}\text { Care for sick or } \\
\text { sequelae patients }\end{array}$ & * \\
\hline & Health maintenance & $*$ \\
\hline \multirow[t]{2}{*}{ Elizabeth. $2010 .^{21}$} & Clinical evaluation & $*$ \\
\hline & Investigation & * \\
\hline
\end{tabular}




\begin{tabular}{|l|l|l|}
\hline & Prevention & $*$ \\
\cline { 2 - 3 } & Assistance and training & $*$ \\
\hline \multirow{2}{*}{ Miller. $1983 .^{22}$} & Multidisciplinary work & $*$ \\
\cline { 2 - 3 } & Decrease of stress & $*$ \\
\hline
\end{tabular}

\begin{tabular}{|l|l|l|}
\hline $\begin{array}{l}\text { Torres González and } \\
\text { Santana Marino. } \\
2017{ }^{23}\end{array}$ & Primary care & \\
\hline $\begin{array}{l}\text { Marchena-Giráldez et } \\
\text { al. 2013. }{ }^{24}\end{array}$ & $\begin{array}{l}\text { Communication and } \\
\text { instruction skills }\end{array}$ & $*$ \\
\hline $\begin{array}{l}\text { Piña López et al. } \\
\text { 2013. }\end{array}$ & Investigation & $*$ \\
\cline { 2 - 3 } & Prevention & $*$ \\
\cline { 2 - 3 } & Rehabilitation & $*$ \\
\hline Piña López, 2004. ${ }^{26}$ & Research for health & $* *$ \\
\hline $\begin{array}{l}\text { Tortella-Feliu et al. } \\
\text { 2016. }{ }^{27}\end{array}$ & Prevention & $*$ \\
\cline { 2 - 3 } & Primary intervention & $*$ \\
\cline { 2 - 3 } & $\begin{array}{l}\text { Mental } \\
\text { promotion }\end{array}$ & $*$ \\
\cline { 2 - 3 } & $\begin{array}{l}\text { Disclosure } \\
\text { psychological } \\
\text { treatments }\end{array}$ & $* *$ \\
\cline { 2 - 3 } & Ethics & $*$ \\
\hline \multirow{2}{*}{ **mply not comply } & & \\
\hline
\end{tabular}

Source: Own elaboration based on the reviewed literature.

From the information reviewed and analyzed, it was found that the competencies mentioned in the literature are mostly those applied at CAPASITS; the only ones not associated are: stress prevention, evaluation and improvement of the healthcare system, secondary and tertiary care, prevention of diseases, use of health technologies (E-health), health research and dissemination of psychological treatments.

It is well known that psychology has been built under a biopsychosocial paradigm, with the purpose of understanding the health-disease processes. Psychology relies on the epidemiological factor of the population, considering psychological therapies as tools in benefit of well-being. ${ }^{11}$

Even though psychology have been considered as a specialized area in therapy, from a clinical perspective, its field has been expanded into different attention levels: primary, secondary and tertiary. ${ }^{12}$ This can be analyzed more clearly in the objectives of health psychology. ${ }^{8}$

In the 70's, in Mexico, the training of psychologists was focused on primary attention services as part of their subspecialization, ${ }^{13}$ with the intention of strengthening those professional competencies of the psychologist. Before this, at the end of the 70's, The National Council for the Teaching and Research in Psychology (CNEIP), announced some recommendations based on the professional profile of the psychologist. ${ }^{3}$ Some of these are:

- $\quad$ Specifying social attention areas where psychologists should act and use technology.

- Identifying prior necessities in the country (according to professional profile), and its temporality (considering historicity)

- Defining the population who will be attended by a psychologist.

- Classifying the processes and the technology uses, considering the number of people who will receive the services and their sociocultural and economical characteristics.

According to APA (1978), health psychologist has the attributes mentioned below. ${ }^{14}$

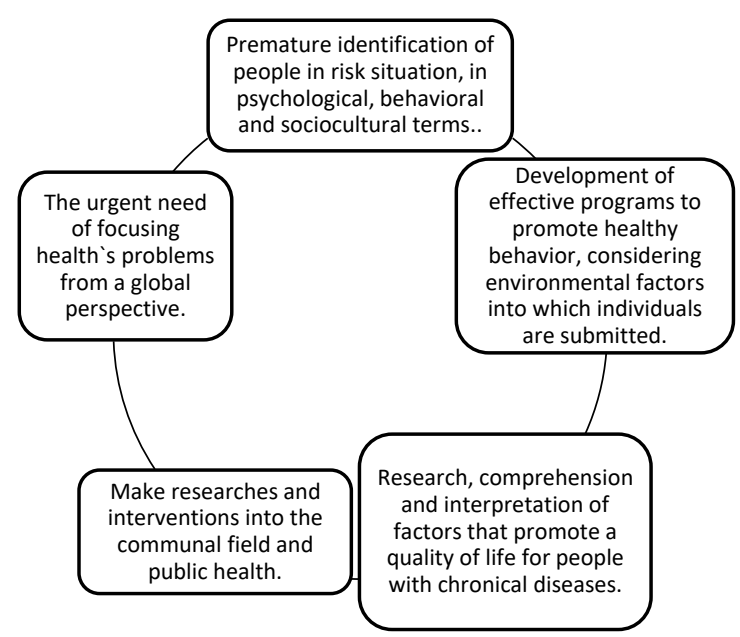

Figure 1. Health psychologist's attributes.

Source: Own elaboration based on the reviewed literature.

The attributions aforementioned should interact in a joint way, so they contribute to maximize the psychologist activity, besides strengthening their professional practice, which must be part of the professional competencies already mentioned by Piña (2010). In contrast, APA does not proposes a sequence of professional attributes, so it is easy to conclude a lack of a process. According to Figure 1, it could be seen a link where one does not necessarily depend on the other, but there is a direct relationship. Derive from this idea, we are referring to the training and professional practice of the health psychologist. ${ }^{14}$

Another concept of health psychology is the one that integrates technology ${ }^{15}$ so that in addition to the above, it was found that the health psychologist must have other competencies related to the Web 2.0, in other words, with Communication and Information Technologies. This is to say that health psychologist should develop skills to use social networks, because they are an excellent media to prevent and promote health. There is "ehealth" or "Health 2.0" (associated elements health and Web 2.0) used as a technological tool for example for: electronic 
clinical history, digitalized psychologic tests, and online psychologic attention. Psychology 2.0 refers to the combination of psychology with Web 2.0 and Health 2.0 to support online prevention and promotion within healthcare and clinical environments. ${ }^{16}$

Among the list of professional competencies/attributes of the psychologist and the meaning of health psychology, it would be appropriate to consider the duality space-time (as the WHO defines health), health psychology could be defined as a professional field where psychologists have the necessary skills and competencies to prevent and promote health. Nonetheless, it is important to recognize that the health psychologist's work is shared with the work of other professionals like physicians, nurses, social workers and others, therefore it can be cataloged as professional, but also as unprofessional regarding the users, so it means having to teach them how to identify health as well as disease. ${ }^{17}$

The health psychologist is strongly influenced by preventing care and health promotion; therefore, a health psychologist could focus on people with HIV or $\mathrm{AIDS}^{8}$ in places like UNEMECAPASITS. Their functions are described below.

CAPASITS is defined as: Ambulatory Center for the Prevention and Attention fof AIDS and sexually transmitted infections. It is a health unit who is responsible for providing services focused on the prevention and care of outpatients with HIV and sexually transmitted diseases. ${ }^{9}$ The former as a fundamental service with a multidisciplinary and interdisciplinary support. ${ }^{18}$

Within the CAPASITS Manual of Procedures, it was found information on the activities of the psychologist in the nineth stage of such document, which includes primary care, where it is mentioned the importance of requiring professional knowledge for the necessary support of patients with VIH / AIDS and other sexually transmitted diseases. ${ }^{19}$

In the Manual of Procedures of CAPASITS there are activities that psychologists must carry out. Next two figures (Figure 2 and Figure 3) describe care processes including psychologist support, from general to particular. ${ }^{19}$

The manual includes six stages and each one of them corresponds to a process that must be respected in order to take care of the patient. Such manual has the objective of "standardizing the procedures that must be done at national CAPASITS, with the purpose of providing an integral outpatient care for every patient with HIV/AIDS and STI; as well as executing activities of prevention, detection and promotion of health, particularly for people in risk and susceptible to HIV and other sexually transmitted diseases, providing a quality, efficient and prompt service; respecting human rights and sexual diversity". 19

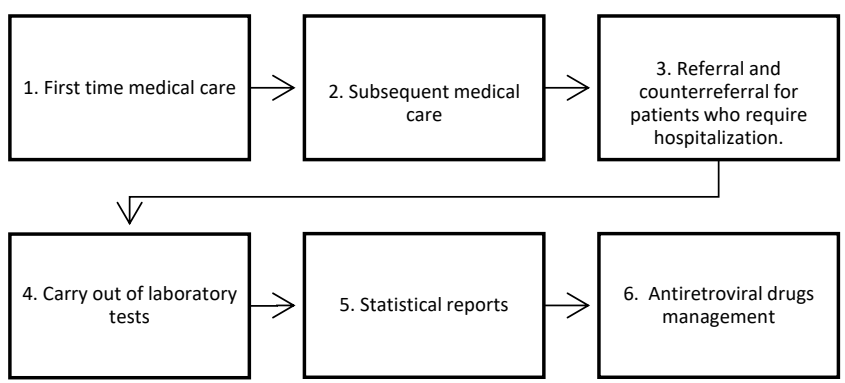

Figure 2. Attention and treatment procedures at CAPASITS Source: Own elaboration based on the Manual of Procedures.

It must be understood that attention provided to patients reaches only procedure number 4 , because procedures 5 and 6 correspond to administrative activities which are carried out by other areas at UNEME. Each of these procedures has its own stage sequence, where activities are systematically specified, with one person responsible for each activity. Next figure shows all procedures related to health psychologist. ${ }^{19}$

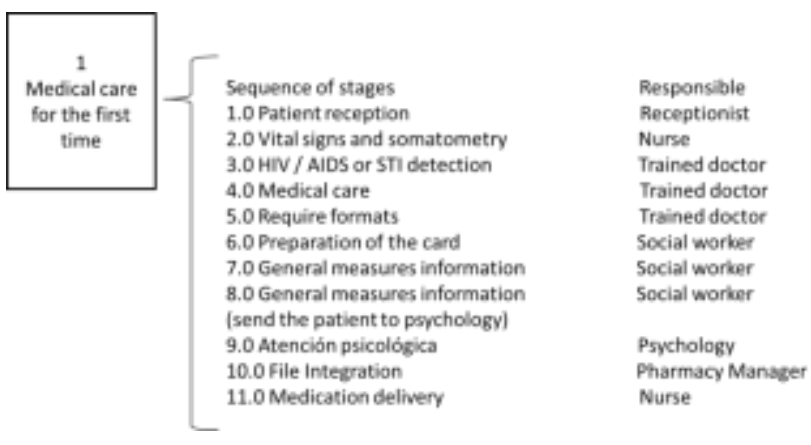

Figure 3. Sequence of stages in first procedure and responsible person.

Source: Own elaboration based on the Manual of Procedures.

First time medical care has 11 stage sequences for a HIV/AIDS or STI patients. Each sequence is in charge of a specific professional. For instance, in the stage sequence 1.0, the receptionist or secretary is the responsible person; and so on and so forth until stage sequence 11.0 with a nurse as a responsible person, finishing all the procedure. Diagnosis, therapy and follow-up for patien should be a multi- and interdisciplinary work, including health professionals and students (social service provider) ${ }^{20}$ Collaborative work should be strict and punctual if the manual's objective wants to be reached. It is also observed that from stage 8 the psychologist activity starts, since it is the moment where the patient is sent to psychological attention, getting to stage 9, where the psychologist is the responsible person. ${ }^{19}$ 
Stage sequence 9 stage refers to psychological care that is where the specific activities derive from as part of the process. The first activities include clinic evaluation trying to make a diagnosis. This is one of the main activities of a health psychologist which allows identifying information that is crucial for the patient's life. So the professional clinical attitude is related to research, evaluation and interaction to understand patient's behavior (to identify internal conflicts) from a psychology point of view. ${ }^{21}$ The former leads to the following process: matching theoryresearch-evaluation methods-therapy. All activities complexity depends on the patient's emotional situation, on the understanding that his/her main disease has a biological origin. ${ }^{22}$ That is why, from the very beginning of the stage sequence, health psychologist plays a critical role in this integral process. ${ }^{19}$

In the last activities of the stage sequence 9 , it is observed that patient is being prepared to refer him/her to the nursing area and continue with the processes. This is how this first procedure ends.

\section{DISCUSSION}

It is worth mentioning that from the authors mentioned in this paper, only Julio Piña ${ }^{3,17,25,26}$ has focused on studying the professional competencies of the health psychologist and their application, making an analysis of them from the curriculum to their application only in Mexico, the rest of the authors, as well as $\mathrm{APA}^{4,8}$ mention or list the competencies that a psychologist must possess.

From what is proposed by APA, health psychology is directly involved with the duality health-disease, making an effort to clarify its nature avoiding possible confusions about the psychologist's field of action. Health psychology could be categorized as investigation, implementation, and training. ${ }^{15}$

Investigation: a fundamental part of their activity. It involves the scientific rigor of its practice.

Implementation: to have the necessary competencies for a development into the healthcare field.

Training: to be aware that their professional life needs continuous updating.

Given the above, we will discuss the need of psychologist's training to develop the required behavioral competencies for their activity. Psychologist's formation requires a certain kind of training that tends to develop its theoretical-conceptual (methodological) and technological skills in duality healthdisease. $^{3}$

As a part of the analysis, it is reaffirmed the importance that each health psychologist involved in on primary health care services must comply with the professional competencies previously mentioned to provide integral health services (physical, mental and social) which are not only related to research for the intervention or design of strategies, that is to say, psychologists must develop competencies for a successful psychosocial attention, where supporting networks can get involved along therapies of patients with chronic diseases. That is why professional competencies must be part of professional training. ${ }^{23}$

Once assessment is finished, as the manual of procedures describes, the type of support is defined. At this point, adherence to treatment is indispensable. In this process, psychologists work with adaptive behaviors using verbal instructions, that is why psychologists must develop this kind of competencies. This activity also shows how communication is developed between patient and health psychologist, there is the importance of this activity, since a therapeutic relationship is created which allows strenghtening the adherence to treatment, and also having a proper follow-up. As a consequence, health is encouraged and, at the same time, patients get educated. ${ }^{4}$

In the case of critical diseases such as HIV/AIDS, a low treatment adherence decreases life quality of the individuals and their family, their "main support network". ${ }^{24}$ It is again inferred the importance of the health psychologist work, since the learning behavioral strategies used through instruction and sensibilization can help the patient adhere to treatment. Health psychologists must focus on primary health care. As a professional, health psychologist should develop disciplinary competencies just as much as in health-disease intervention. ${ }^{25}$ Even if health psychologists possess competencies, there is a question that must be responded: How to develop work proposals that allow consolidating a decisive presence and participation of psychologists within interdisciplinary health teams inside institutions?. ${ }^{25}$

At CAPASITS, the importance of psychologists' activities lies on a professional and multidisciplinary support, required for treatment adherence and follow-up. Along the six stages into procedure manual, health psychologists' participation is limited, because most of processes are administrative. In this sense, health institutions require an integral and high quality intervention on behalf of health psychologists, focused on preventing chronic diseases and rehabilitation, based on questions about when, how or why they should take action. They should also propose improvements to intervention programs. Intervention programs must consider recent researches and their results, and take into consideration how psychologic phenomena intervene in the clinical aspect of chronic diseases. ${ }^{25}$ Therefore, the activity of psychologists throughout healthcare attention is fundamental in the strict sense of prevention and support within the multidisciplinary field, since human behavior (both psychological and social) is involved. Some of the contributions of Mexican psychologists are focused on general health materials and basic health services. ${ }^{26}$

There are many challenges that health psychologists must face, such as research and individual differences. That is to say, how therapies impact positively (decreasing symptoms) on 
psychological disorders. Moving forward regarding the knowledge about why or to whom psychologic intervention favors, would optimize therapies. ${ }^{27}$

\section{CONCLUSIONS}

Health psychologists must possess professional competencies, developed along its professional training, that allow them a specialized practice in the field of health. ${ }^{3}$ All UNEME CAPASITS demand a professional training in communication, Information and Communication Technologies, research, therapeutic evaluation, follow-up, and clinic files report skills. ${ }^{17}$ However, there are competencies that are mentioned in the literature that complement and strengthen their activity, such as: research on health and the dissemination of results, especially in treatments. ${ }^{26,27}$ It must be considered that the manual of procedures only contains functions of the psychologist at stage 9. ${ }^{19}$

Nowadays, health psychologists must have professional competencies that can guarantee a training that can have a positive impact on society's health or at whatever the psychologists' environment is, with strategies that promote health or prevent diseases. ${ }^{14}$

\section{REFERENCES}

[1] Garofalo JP, Baum A. Behavioral medicine: treating disease and mental health. Curr. Opin. Psychiatr. 1998;11(6):597-9.

[2] Bazán Riveron GE. Contribuciones de la psicología de la salud en el ámbito hospitalario de México. Psic. Cienc. Soc. 2003;5(1):20-6.

[3] Piña López JA. El rol del psicólogo en al ámbito de la salud: de las funciones a las competencias profesionales. Ense. Inve. Psic. 2010;15(2):233-55.

[4] Matarazzo JD. Behavioral health's challenge to academic, scientific, and professional psychology. Am. Psychol. 1982;37(1):1-14.

[5] World Health Organization. ¿Cómo define la OMS la salud? Available from: https://www.who.int/es/about/who-we-are/frequently-askedquestions [Accessed 3 febrero 2020].

[6] Saavedra Solano N, Berenzon Gorn S, Galván Reyes J. Salud mental y atención primaria en México. Posibilidades y retos. Aten. Primaria. 2016;48(4):258-64.

[7] Oblitas LA, Iglesias E. Psicología de la salud. In: Becoña E, Vázquez FL, Oblitas LA, editors. Psicología de la salud: antecedentes, desarrollo, estado actual y perspectivas. México: Plaza y Vladés; 2000: 11-43.

[8] Oblitas LA. El estado del arte de la Psicología de la Salud. Rev. Psicol. 2008;26(2):219-54.

[9] Centro Nacional para la Prevención y Control del VIH y el sida. Centros de atención SAIH y CAPASITS. Available from: https://www.gob.mx/censida/acciones-y-programas/centros-de-atencionsais-y-capasits [Accessed 9 February 2019].

[10] Guirao S. Utilidad y tipos de revisión bibliográfica. ENE Rev. Enf. $2015 ; 9(2)$

[11] Péres Rosiles L, Márquez Barradas ML. La psicología de la salud: una perspectiva con futuro. LIBERABIT. 2000;6:61-8.
[12] Fernandes Alves R, Jiménez-Brobeil SA, Eulálio MC, Andrade DA, Cunha ECN, Araújo Ferreira PR. Intervenciones de psicólogos en la salud pública de Brasil, España y Portugal. Rev. Psic. 2016;34(2):357-86.

[13] Reynoso L, Seligson I. Psicología y Salud. In: Reynoso L, Seligson I, editors. Psicología y salud en México. México: Universidad Nacional Autónoma de México; 2002: 13-32.

[14] Werner Sebastiani R, Pelicioni, MCF., Chiattone HBC. La Psicología de la Salud Latinoamericana: hacia la promoción de la salud. RIPCS/IJCHP. 2002;2(1):153-72.

[15] Weiss SM. Health Psychology: The time is now. Heal. Psychol. 1982;1(1):81-91.

[16] Armayones M, Boixadós M, Gómez B, Guillamón N, Hernández E, Nieto R, et al. Psicología 2.0: Oportunidades y retos para el profesional de la psicología en el ámbito de la esalud. Paps. Psic. 2015;36(2):153-60.

[17] Piña J, Rivera B. Psicología De La Salud: Algunas reflexiones críticas sobre su qué y su para qué. Univ. Psychol. 2006;5(3):669-79.

[18] World Health Organization. VIH/sida. Available from: https://www.who.int/es/news-room/fact-sheets/detail/hiv-aids [Accessed 6 February 2020].

[19] CENSIDA. Centro Nacional Para La Prevención Y El Control Del Vih / Sida Manual De Procedimientos Prevención Y Atención Del Sida E Infecciones De Transmisión Sexual. 2010;1-58. Available from: www.censida.salud.gob.mx/descargas/Man_ProcedCAPASITS_10.pdf

[20] Díaz Facio Lince VE. La psicología de la salud: antecedentes, definición y perspectivas. Rev. Psicol. Univ. Antioquia. 2010;2(1). 57-71.

[21] Elizabeth J. La evaluación clínica como una función integral del psicólogo. Pers. Psic. Rev. Psic. Cien. Afn. 2018;15(1):113-22.

[22] Miller NE. Behavioral Medicine: Symbiosis between Laboratory and Clinic. Ann. Rev. Psychol. 1983;34:1-31.

[23] Torres González YM, Santana Mariño J. Programa De Psicología De La Salud Y Cuidado Primario: Un Modelo De Adiestramiento Pre-Doctoral. Rev. Puertorriq. Psic. 2017;28(2):316-33.

[24] Marchena-Giráldez C, Calero-Elvira A, Galván-Domínguez N. La importancia de las instrucciones del psicólogo para favorecer la adhesión terapéutica. Clin. Sal. 2013;24:55-65.

[25] Piña López JA, Sánchez-Bravo C, García-Cedillo I, Ybarra Sagarduy JL, García Cadena CH. Psicología y salud en México: algunas reflexiones basadas en el sentido común y la experiencia. Divers. Perspect. Psicol. 2013;9(2):347-60.

[26] Piña López JA. La psicología y los psicólogos en el sector de la salud en México: algunas realidades perturbadoras. IJCHP. 2004;4(1):191-205.

[27] Tortella-Feliu M, Vázquez C, Valiente C, Quero S, Soler J, Montorio I, et al. Retos en el desarrollo de intervenciones psicológicas y la práctica asistencial en salud mental. Clin. Sal. 2016;27(2):65-71. 